\title{
New Zealand Legal History and New Zealand Historians: A Non-meeting of Minds
}

\section{RICHARD BOAST ${ }^{1}$}

This article is about New Zealand legal historiography. This is a thriving, if relatively new sub-field of New Zealand historical studies - a new kid on the historical block as it were. For it remains the case that the law has not penetrated very deeply into the consciousness of historians who teach in the history departments (as opposed to we historians who earn our daily bread in the law schools: although our interests are no less historical and historiographical, we do find ourselves distracted by having to teach complicated courses on the law of real property or equitable obligations to crowded classrooms of law students).

The low value historians place on legal history is evident in The New Oxford History of New Zealand, published in 2009. ${ }^{2}$ The book is certainly well-produced and is a collection of stimulating essays by some of our more prominent historians. It is indeed an excellent and interesting tome and the editor and the contributors all deserve our thanks. It has well-written chapters on health, sexuality, 'sporting spaces', religion and society, on the family, community, and gender - but not on the law and the legal system. Surely it is not just a reflection of a legal academic's prejudice to feel that the law and the constitution might possibly be just as important as sport in the history of our country. One scans the index of the New Oxford in vain for any reference to the Court of Appeal, Sir John Salmond - our most important jurist - or even (incredibly) the Privy Council. There is more about tennis and soccer in the book than there is about the Courts. The only Court that gets referred to is the Maori Land Court (there is also some material about industrial conciliation and arbitration) and there is not much in the book even about that. I am a specialist in the history of the Maori Land Court but, frankly, to imply that it is of more importance in our country's history than the Court of Appeal or the Privy Council is absurd.

There is nothing about the development of New Zealand common law and coverage of statute law is a bit uneven. Bronwyn Labrum's essay on welfare law does indeed list the principal social welfare statutes. ${ }^{3}$ There is a long section on the Homosexual Law Reform Act. That is about it. There is no 
mention of, say, the Land Transfer Act 1870, a revolutionary statute based on legal reforms in South Australia, which brought the vitally important Torrens system into New Zealand, without which the clear titles and credit that underpinned the settlement of the North Island bush frontier would not have been possible and which remains vitally important today. ${ }^{4}$ The Crimes Act and the Constitution Act do not rate a mention. Nor is there any mention of Sir Owen Woodhouse or the Woodhouse report. Surely the ending of the tort system for personal injuries and its replacement by the accident compensation system (ACC) was an important event in our history, one which - I would have thought - could have been usefully engaged with to deal with some of the more general themes in the book. But the only statement about the accident compensation system - in the sport chapter is the assertion that men were the principal beneficiaries of it. ${ }^{5}$ There is a great deal more that could have been said. New Zealanders get injured in car crashes, at work and around the house more often than they do on the sports field. The accident compensation system established in New Zealand was the first of its kind anywhere in the world, and exemplifies New Zealand's strongly reformist and statute-based approach to legal development. Other examples include the establishment of the Waitangi Tribunal with the Treaty of Waitangi Act 1975, the enactment of a comprehensive code of environmental management with the Resource Management Act 1991, and a long history of statutes nationalizing key natural resources, including the Petroleum Act 1937, the Geothermal Energy Act 1954 and the Water and Soil Conservation Act $1967 .{ }^{6}$ Such laws are of interest not only to lawyers. Rather they exemplify something important about the very nature of this country and its way of doing things. A key aspect of New Zealand reality has been overlooked. Clearly those responsible for putting together the New Oxford have concluded that the undergraduate and senior secondary school student audience for whom the book is presumably intended do not need to know anything about the law. There is not in fact much in the book about the constitutional structure and history of the country at all, perhaps because the authors regard it as a bit fuddy-duddy and boring, or at least are concerned that the book's readers might find it so. I couldn't find anything about the Abolition of the Provinces Act, for example, or about the abolition of the legislative council, although both are covered in the first edition of the Oxford History.

Absence of law seems to be a peculiarity of our Oxford history: for example there is a lot about law - and crime, and violence - in The Oxford History of the American West and in The Oxford History of Mexico. The Oxford Illustrated History of Tudor and Stuart England actually has an entire chapter about law and litigation. ${ }^{7}$ There is, as one would expect, 
plenty about law in The Oxford History of Islam. ${ }^{8}$ The law in Early Modern England is an issue of considerable importance in that complex and turbulent world, so no doubt it deserves a chapter all to itself. Law is of course a vital component of Islamic civilization. But is it of no significance in nineteenth- and twentieth-century New Zealand? Is New Zealand somehow uniquely different from Early Modern Britain, the American West, Mexico and the Islamic world as a place where law did not matter? There is more about law in The Oxford Illustrated History of the Crusades ${ }^{9}$ than there is the New Oxford History of New Zealand. It seems bizarre to think the law might matter less to New Zealanders than it did in the Latin Kingdom of Jerusalem. There is no need to go on. Perhaps it is of some comfort to us lawyers that law is classed with science as a topic of significant uninterest. Sir Ernest Rutherford is missing from the index as well.

It is not as if there is no accessible literature about New Zealand legal history that could have been drawn on. There is a textbook on New Zealand legal history that has now gone into its second edition, which is - I like to think - well-regarded, and which has certainly been well-reviewed..$^{10}$ There are a number of very solid comparative studies by New Zealand scholars of aspects of colonial legal history. ${ }^{11}$ There are also a number of readily accessible books on the history of the Court of Appeal, on the legal profession, and on crime and the prisons (not listed in the New Oxford, however). Richard Hill and others have produced a massive series of books on the history of policing in New Zealand. ${ }^{12}$ My law school at Victoria University hosted a conference a couple of years ago on Sir John Salmond which drew attendees and presenters from all round the world and which resulted in a book of essays about him and his legacy (not all of them hagiographical or technical by any means). ${ }^{13}$ We legal historians are known to read the New Zealand Journal of History and even Past and Present as well as the Journal of Legal History. Our colleagues in the history departments do not however seem to be very conversant with the Victoria University of Wellington Law Review or any other of New Zealand's dozen or so academic law reviews, all of them fully-refereed journals, which have published a considerable body of material on New Zealand history (none of which is cited in the New Oxford). In 2004 the Victoria University of Wellington Law Review devoted an entire bulky issue to New Zealand legal history, with detailed and scholarly reviews of early colonial case law, studies of nineteenth-century judges and so forth. ${ }^{14}$ Many other articles on aspects of New Zealand legal history have been published in its pages from time to time..$^{15}$ Some recognition of all this in our flagship New Zealand history textbook would have been nice. New Zealand legal historians are a growing and industrious community but on the whole we are left to talk to ourselves. 
I do not mean by any of this to launch a tirade against the Oxford History. I also accept that legal historians, immersed in their own field, might sometimes be prone to over-estimate the significance of the law and overlook other equally compelling aspects of human life and endeavour. Legal history is but one aspect of history, and not always a very important aspect. My point is simply that the law is nevertheless a key part of society and history and its total absence from the Oxford History is genuinely disconcerting. The problem is that the Oxford History is not just any history book. It is, rather, our key text, the principal history textbook for undergraduate and senior secondary school students, the first serious history textbook that our future historians will be reading. That it ignores the law is thus a concern. But perhaps the absence of law from its pages is symptomatic of something about current New Zealand historiography.

There is definitely something of a blind spot about the law in the history departments. A number (I would not go so far as to say 'many') legal academics are engaged in historical research, but very few academics specializing in New Zealand history are interested in law, seemingly. Why is this? It seems to me that New Zealand legal historiography is in the same state that English legal historiography was until 1975. Before then, plenty was written on English legal historiography, but it was written by legal academics (I do not mean to include in the genre of "legal history" the kind of books one can find in the more neglected recesses of any large law library: Forty Years on the Western Circuit by A Barrister - collections of funny, or tedious, courtroom stories). I have in mind, for example, Sir Leon Radzinowicz's great History of English Criminal Law, a grand narrative in ultra-Whig style published in a series of solid volumes under the prestigious imprint of the Cambridge University Press from 1948 onwards. ${ }^{16}$ Radzinowicz taught in the Cambridge Law School and his massive work is a foundational text, even if its basic historiographical stance - how a brutal and capricious eighteenth-century system founded on public capital executions was reformed and replaced by a heroic group of embattled reformers such as Romilly and Peel - is no longer regarded as convincing by everyone. Radzinowicz was a legal academic, who wrote for other legal academics - most of whom are more interested in the new, the latest cases and statutes, rather than the old - and who was more or less unknown outside the law schools.

What revolutionized all this was a book published in 1975, one of the few equally well-known both to legal and to historical academics, produced by a group of North American and British scholars led by E.P. Thompson at Warwick University. The book was Albion's Fatal Tree, a collection of essays on various aspects of crime and the courts in the eighteenth century and it contained a seminal paper by Douglas Hay - a Canadian - called 'Property, Authority and the Criminal Law' - still given to many law students 
to read to this day. ${ }^{17}$ Most of the contributors to Albion's Fatal Tree were Marxists of an English Christopher Hill/E.P. Thompson stamp, and Hay was - and, indeed, still is - no exception. He argued that the purpose of the criminal justice system was not crime control at all but the maintenance of class rule by 'the propertied' through and by means of the criminal justice system, especially through the exercise of discretions in prosecuting, at trial and in the granting of pardons, using in his analysis the general concepts of terror, justice, and mercy. The contributors to Albion's Fatal Tree were - reverting to my main theme - not legal academics but teachers in a history department, and the book was the precursor of a major influx of history department academics into the space of crime and the criminal law till then largely abandoned to the law schools. Langbein soon produced a stinging attack on Hay's paper, ${ }^{18}$ followed in turn by a counter-attack on Langbein by another contributor to Albion's Fatal Tree, and the debate took off. ${ }^{19}$ It shows no sign of abating and it is an enterprise in which professors in history departments (for example John Beattie ${ }^{20}$ ) and in the law schools (J.H.Langbein in particular ${ }^{21}$ ) have shared.

Also in 1975 an equally ground-breaking book was published in France, Foucault's Surveiller et Punir, translated into English in 1977 - not quite accurately - as Discipline and Punish. ${ }^{22}$ Whether one likes Foucault-style determinism or not, it cannot be denied that this book has been of enormous historiographical importance, reinforcing the unleashing of debate caused by Albion's Fatal Tree. Foucault's book led historians into new areas of coercion and control - capital punishment, imprisonment, the design of prison buildings, institutional confinement of the insane and so forth. But also, and even more importantly, he stood the Whig approach to criminal justice reform on its head, arguing that the objectives of the nineteenth-century reformers were much more sinister and totalitarian than the eighteenthcentury system in all its brutality. In the classic age of monarchical Europe it was sufficient to engrave the sovereign's displeasure on malefactors by brutal physical punishments as part of a public spectacle; the nineteenth-century reformers were interested, however, in remodelling the soul through close supervision, inspection and discipline of the body behind closed walls. To say this gave historians of crime and criminal justice food for thought is to put it mildly.

This new criminal justice history, which certainly gets an airing in the law schools, has not made much impact on mainstream New Zealand historiography which until very recently ${ }^{23}$ has seemed curiously uninterested in crime, prisons, confinement, the treatment of the mad, or the objectives of nineteenth-century reformers. Greg Newbold and John Pratt have dealt very well with aspects of this history, certainly, but it has not emerged as a major component of historical studies in New Zealand in the same way as 
it has in Britain, France, the United States or Australia. It is not as if there is no New Zealand material to work with - as any reader of Janet Frame's autobiography will know. We were, and are, as carceral and confining as anyone else. Few New Zealanders are even aware of the fact that our malefactors, like the English, were sentenced to transportation - although compared to English and Irish convicts, the voyage was not a long one - and were shipped to Van Diemen's Land until 1859. The use of the Chatham Islands as a penal colony for Maori dissidents from the East Coast or the confinement of Maori military prisoners on hulks near Auckland - from both of which they escaped - do seem to be entry points by which the new criminal justice historiography could be connected with broader themes in New Zealand history: a case of race relations history meeting Hay and Langbein. ${ }^{24}$

On the opposite side of the Tasman the new criminal justice history has had a major impact because of the origins of a number of the Australian colonies as penal colonies. Crime and punishment is a pivotal dimension to the history of New South Wales, Tasmania and Norfolk Island. Transportation has been a major focus of the new criminal justice historiography, a field which includes many distinguished Australian names. ${ }^{25} \mathrm{~A}$ fascinating historiography over whether transportation to Australia should be seen as part of Australia's migration and labour history has emerged, and there has been an equally interesting debate over women convicts and their role in the colony. ${ }^{26}$ Such a historiography must, of course, engage with the law:with the Transportation Act and the Hulks Act, with the penal crisis during the American Revolutionary war - when the option of transportation to the Middle Atlantic colonies, the favoured destination till then, suddenly became unavailable - and with the legal rights of convicts in New South Wales and the other penal colonies. ${ }^{27}$ In the words of the popular song, saying 'farewell to the well-known Old Bailey' is a key part of Australian historical identity. Unfortunately, not being a penal colony, this is a historiographical stimulus New Zealand has lacked. The Australian penal colonies were not the only ones in our region, as it happens. New Caledonia was a penal colony for much of its history, and is famous in French historiography as being the destination for many of the Communards following the defeat of the Paris Commune. ${ }^{28}$ A regional penal history of the southwest Pacific, including New Zealand, would be an interesting project.

In one area there has definitely been a massive upsurge in research in New Zealand. The Waitangi Tribunal and related processes have greatly stimulated historical enquiry into the Native Land Court, Crown land purchasing from Maori, confiscation and confiscation law, the law relating to land development schemes and Maori land tenure generally. ${ }^{29}$ Few countries have put their colonial history under the microscope to the extent that New 
Zealand has over the last few decades, and much of this research has had to engage with the law in one way or another. The amount of material that has now been produced is very substantial and much of it of excellent quality. ${ }^{30}$ This upsurge has created a job market for history graduates and a new career path for historians, where once there was only academia for a favoured few and secondary school teaching for everyone else. Public or contract history is very much a reality in New Zealand. Within the pool of contractors and public historians there is a smaller group of what can be described as contracting or practising contract legal historians who are able to deal with both historical primary research and historiographical debate as well as the legal technicalities of the statutes relating to the Native Land Court, confiscation and so on.

As the research mountain has grown, a number of earlier certainties of course have vanished, or have at least been called into question. Take for instance the Native Land Court. Not too long ago we thought we knew all about the Native Land Court. It was, as Hugh Kawharu said, 'an engine of destruction' for any tribe's land, anywhere. It applied rigid narrow take or causes of action, fitting the complexities of Maori land tenure into an impossible straightjacket. The judges knew nothing about Maori tenure. If Maori could not attend Court then the cases went ahead without them. The Court wasn't even a Court, just an arm of the state. Its task was to make land buying easy for 'settlers'. And so forth. The picture of the Court that is now emerging is somewhat more nuanced. Some of what used to be said and believed about the Court is only too true, some of it less so. It turns out, at least some of the time, to have maintained a reasonably robust judicial independence. There were in fact a number of serious clashes between the government of the day and the Native Land Court. Far from exhibiting doctrinal rigidity, if anything the opposite was the case: the Court was basically pragmatic. There is an old lawyer's joke about the Irish Court of Chancery, which says that in this court no case was certain, but none hopeless. The Native Land Court was a little like that, but it did not always get it wrong - or right - about customary tenure. There were no rigid take (causes of action, or roots of title), that much is clear. The Court did not always race recklessly ahead if parties could not be present: in fact adjournments were allowed all the time. I paint a somewhat revisionist picture of the Court in my own book, placing it where I believe it belongs: as a prelude to what was really the most damaging development, the Crown purchasing system. ${ }^{31}$ Even after the establishment of the Court the principal purchaser of Maori land continued to be the state.

There is certainly a large and growing literature on what might be called the legal history of Maori-Crown interaction, although there is much that is not altogether satisfactory about the current situation in terms of research. 
The 'research' is being done essentially as evidence to support a particular kind of litigation carried out before a specialist tribunal set up by statute. I do not mean to suggest that this necessarily means such work lacks credibility, although it is inevitably the case that when one is writing evidence for either the Crown or for claimants this will structure the research and the text in a number of ways. ${ }^{32}$ Nevertheless, the real problems I believe relate more to availability and accessibility. A very large amount of money is being spent and a great deal has been written, some of it of outstanding quality, but it overwhelmingly exists in the grey literature of the Waitangi Tribunal process. The work is simply sitting in Archive boxes or on the shelves of the Waitangi Tribunal library, or scattered around the claimants and law firms specializing in the area (the Maori Legal Services team at Kensington Swan has maintained a meticulous collection, as I happen to know). Of course the various historians involved can always republish their work themselves in monographs and journal articles, and this is now happening with increasing frequency. ${ }^{33}$ But given the degree of effort, time and resources that have been poured into the process it seems imperative to me that everything done for the inquiries on the public records should be digitized and made available for anyone to consult. This has to be the largest historical research project that has ever been done in our country's legal history. It will not be repeated. It would be a shame if it all got lost.

There are now courses on legal history in most of the country's law schools. Those of us who teach these courses are in fact historians, albeit lawyers as well. The course at Victoria had an enrolment in 2010 of about 70 students, making it one of the more popular of our third and fourth year options. Students take it because they are interested in history, and indeed at least a third of the class have done history at tertiary level (a high percentage of law students in fact do conjoint degrees, mostly in Arts). And, as noted, there is something of a niche market these days for graduates in law and history, although how long this will last is hard to say. The present government has set a 2014 deadline for the final resolution of all historic Maori claims against the Crown, a deadline which most people who know anything about the current negotiation and settlement process regard as laughable. The need for specialist historical research and input will not be coming to an end anytime soon. It is interesting that the type of professional expertise most in demand in the Waitangi Tribunal process is that of historians. This can be contrasted with the Native Title tribunal process in Australia, which is dominated by anthropologists. This is a consequence of the quite dissimilar processes of inquiry: the Waitangi Tribunal process involves wide-ranging and detailed inquiries into history, but the Native Title process in Australia revolves around whether the claimant group have maintained themselves in situ and continue to exercise customary law. Those 
who like to decry the 'Treaty industry' - why, I wonder, do we never hear of the vastly larger and more costly tax and crime 'industries' - seem to believe that the process has mainly widened the doors of opportunity for lawyers. But in fact the professional group that has probably had the widest new range of opportunities opened to it are historians. Lawyers can always find something to do, but a large new field for commissioned historical research does not come along very often.

As well as teachers in the universities, there is a growing community of legal practitioners who are professionally interested in history, have $\mathrm{PhD}$ and MA degrees in it, and who write books and articles on the subject when they are not drafting documents or arguing cases. There is some talk overseas of a 'New Zealand school of legal history' which is seen as heavily Pocockian and contextual, and some of us do fit that bill. The history of political thought, jurisprudence, and law fit together very well, and John Pocock himself, the master, is very interested in the Common Law and in the rhetoric of law in the seventeenth-century. He likes also to stress his own strong New Zealand links. As Pocock has long insisted, the Common Law is in itself a historical method, of a kind. If any kind of history deserves to be called Whig history it is Common Law historical technique, the very point of which is teleological. But not all of us look to Cambridge for enlightenment or inspiration. Some of us are purely local products who have never been able to get near the dreaming spires; others have grown up in the combative field of Australian historical studies and are interested in trans-Tasman connections and disassociations. While I am as fascinated by the English seventeenth-century as anyone, my personal field of comparison and inspiration latterly has been Latin America. New Zealand has more structural affinities with Guatemala than we might care to admit. So there is no dominant historiographical trend or leaning that can as yet be clearly identified. Nevertheless we are here; we have arrived.

As a first step in placing a new New Zealand legal history on surer foundations, a major research project has been embarked on. Driven by the estimable Dr Shaunnagh Dorsett, ${ }^{34}$ Geoff McLay and Megan Simpson of Victoria University of Wellington, this project has begun to assemble vast quantities of early New Zealand case law and place it on the internet for all to see..$^{35}$ New Zealand, as a common law country, bases its law on the principle of stare decisis: decisions of the Courts are a source of law in their own right, earlier decisions bind later ones, if on point - the room for subtle manoeuvre is large - and higher Courts bind lower. Inherent in such a legal world-view is the need for reported cases to be published and widely available, so that practitioners can consult them and carry the precedents into the courtroom, or these days consult them on their lap-tops. The elaboration of complex doctrine through precedent is principally what law students learn 
about in law school. In New Zealand there was no national system of law reporting - that is, publication of leading cases decided in the superior courts (95\% per cent of the business of the Courts never gets reported) - until the 1870s. Monographs and published editions of case law are envisaged. This new material is already posing some interesting questions. As if in fulfilment of some Australian joke about us, a lot of the cases seem to be about sheep - mostly, however, about buying and selling sheep, liens over sheep, and lost sheep, I am happy to say (It might be interesting to do a comparative survey of sheep litigation on either side of the Tasman to finally lay this to rest). Fascinating issues have arisen about the extent to which Maori were able to give evidence in New Zealand courts in the 1840s and 1850 s, or the extent to which Maori people sued one another in the early Courts (to which the answers seem to be, they could indeed, and quite a bit). Another equally significant research project led by Māmari Stephens, also being carried out at the Law School at Victoria, is a major linguistic study of the use of legal terminology in Maori-language documents. ${ }^{36}$ The corpus of documentary material that has had to be reviewed can only be described as colossal. The end-point of the research will be a historical dictionary of Maori legal terminology, which will be of great interest not only in New Zealand but in the international historical community. The relationship between language, legal texts and colonization is a burgeoning field, ${ }^{37}$ to which New Zealand can certainly make a valuable contribution given the sheer volume of available documents written in the indigenous language (compared with, say, Nahuatl or Mixtec). What I would hope to persuade non-legal historians of, is that this material might be of interest to them. We are not just concerned about the evolution of doctrine, but about the law as a window into our history. Surely that is a project for many with an interest in New Zealand history to take up. One hopes that a fourth edition of the Oxford History might reflect some of these developments.

1 Professor of Law, Victoria University of Wellington, barrister.

2 Giselle Byrnes, ed., The New Oxford History of New Zealand, Melbourne, 2009.

3 Bronwyn Labrum, 'The Changing Meanings and Practices of Welfare, 1840s-1880s', in Byrnes, ed., The New Oxford History of New Zealand, pp.389-422.

4 For a comparative survey of "Torrens" statutes see especially S. Rowton Simpson, Land, Law and Registration, Cambridge, 1978.

5 The intriguing suggestion is made that the availability of accident compensation is one reason why adventure tourism has taken off in New Zealand. Maybe so - I am not sure about that at all. Adventure tourism is big business in, for example, Costa Rica, which lacks any equivalent to ACC.

6 It is interesting that the current Oxford text on New Zealand environmental history, Eric Pawson and Tom Brooking, eds, Environmental Histories of New Zealand, Melbourne, 2002, has a great deal of material about law, including a chapter on the history of 
environmental law in New Zealand by Nicola Wheen of the School of Law at Otago University (pp.261-74).

7 See Christopher Brooks, 'A Law-abiding and Litigious Society', in John Morrill, ed., The Oxford Illustrated History of Tudor and Stuart Britain, Oxford, 1996, pp.139-55.

8 John L. Esposito, ed., The Oxford History of Islam, Oxford, 1999. It gets an entire excellent chapter by Mohammed Hashim Kamali ('Law and Society: The Interplay of Revelation and Reason in the Shariah', pp.107-54).

9 See Jonathan Riley-Smith, ed., The Oxford Illustrated History of the Crusades, Oxford and New York, 1995, pp.5, 71, 134-6, 245.

10 Peter Spiller, Jeremy Finn and Richard Boast, A New Zealand Legal History, 2nd ed., Wellington, 2001.

11 Most notably P.G. McHugh, Aboriginal Societies and the Common Law: A History of Sovereignty, Status and Self-determination, Oxford, 2004.

12 See for example, Richard Hill, Policing the Colonial Frontier: The Theory and Practice of Coercive Social and Racial Control in New Zealand, 1767-1867, Part One, two vols, Wellington, 1986.

13 Victoria University of Wellington Law Review (VUWLR), 38, 4 (2008). Contributions included P.G. McHugh, 'Sir John Salmond and the Moral Agency of the State', p.743; Shaunnagh Dorsett and Shaun McVeigh, 'The Persona of the Jurist in Salmond's Jurisprudence', p.771; R.P. Boast, 'Sir John Salmond and Maori Land Tenure', p.831; and Mark Hickford, 'John Salmond and Native Title in New Zealand: Developing a Crown Theory on the Treaty of Waitangi, 1910-1920', p.853.

14 "Forgotten" Cases and "Forgotten Research": Legal History Special Issue, VUWLR, 35, 1 (2004).

15 For example, R.P. Boast, 'Recognising Multi-Textualism: Rethinking New Zealand's Legal History', VUWLR, 37, 4 (2006), pp.547-82.

16 Leon Radzinowicz, History of English Criminal Law and its Administration from 1750, four vols, Cambridge, 1948-1968.

17 Douglas Hay, 'Property, Authority and the Criminal Law' in Douglas Hay et al., Albion's Fatal Tree: Crime and Society in Eighteenth-Century England, London, 1975. I use Hay's chapter as a key text in my own Legal History course at Victoria University of Wellington, as do many other teachers of such courses in Britain, Australia, and the United States.

18 J.H. Langbein, 'Albion's Fatal Flaws', Past and Present, 98 (1983), p.96-120.

19 Peter Linebaugh, '(Marxist) Social History and (Conservative) Legal History: A Reply to Professor Langbein', New York University Law Review, 60 (1985), pp.212-43.

20 J.M. Beattie, Crime and the Courts in England, Oxford, 1986; Beattie, Policing and Punishment in London 1660-1750: Urban Crime and the Limits of Terror, New York, 2001. For reviews of the literature see Joanna Innes and John Styles, 'The Crime Wave: Recent Writing on Crime and Criminal Justice in Eighteenth-Century England', Journal of British Studies, 25, 4 (1986), pp.380-435; Bruce P. Smith, 'English Criminal Justice Administration, 1650-1850: A Historiographic Essay', Law and History Review (LHR), 25 (2007), pp.593-634.

21 See J.H. Langbein, 'The Historical Origins of the Sanction of Imprisonment for Serious Crime', Journal of Legal Studies, 5, 1 (1976), pp.35-60; 'The Criminal Trial before the Lawyers', University of Chicago Law Review, 45 (1978), pp.263-316; 'Shaping the Criminal Trial: A View from the Ryder Sources', University of Chicago Law Review, 50 (1983), p.1; 'The Historical Origins of the Privilege Against Self-incrimination at Common Law', Michigan Law Review, 92, 5 (1994), p.1047; 'Historical Foundations of 


\section{Journal of New Zealand Studies}

the Law of Evidence: A View from the Ryder Sources', Columbia Law Review, 96, 5 (1996), p.1168; 'The Prosecutorial Origins of Defence Counsel in the Eighteenth Century: The Appearance of Solicitors', Cambridge Law Journal, 58 (1999), p.314; The Origins of Adversary Criminal Trial, Oxford, 2003.

22 Michel Foucault, Discipline and Punish (translation of Surveiller et Punir, Paris, 1975), New York, 1995 ('To inspect and punish', or 'Inspection and Punishment' would be more precise translations). On the historiographical significance of Discipline and Punish see especially David Garland, Punishment and Modern Society, Oxford, 1990, pp.131-76.

23 For a recent discussion of insanity, see Catharine Coleborne, Madness in the Family: Insanity and Institutions in the Australasian Colonial World, 1860-1914 (Basingstoke and New York, 2010), reviewed in this issue. See also Angela McCarthy's paper in this issue.

24 Judith Binney certainly discusses the use of the Chatham Islands as a penal colony in her celebrated biography of Te Kooti: see Binney, Redemption Songs: A Life of Te Kooti Arikirangi Te Turuki, Auckland, 1995, pp.63-86. What I mean is that we lack a published history of the use of penal colonies, the hulks and transportation as a component of the wider history of the New Zealand wars in its own right.

25 See for example, Bruce Kercher, 'Perish or Prosper: The Law and Convict Transportation in the British Empire', LHR, 21 (2003), p.527.

26 Stephen Nicolas, ed., Convict Workers: Reinterpreting Australia's Past, Cambridge, 1988. On women convicts see Kay Daniels, Convict Women, Melbourne, 1998; Deborah Oxley, Convict Maids: The Forced Migration of Women to Australia, Cambridge and Melbourne, 1996; Portia Robinson, The Women of Botany Bay, Revised ed., Melbourne, 1993.

27 See especially David Neal, The Rule of Law in a Penal Colony: Law and Power in Early New South Wales, Cambridge, 1991.

28 See Louis-José Barbançon, L'Archipel des Forçats: Histoire du bagne de NouvelleCalédonie, Paris, 2003. Transportation of Algerian political prisoners to New Caledonia in the nineteenth century has created one of the southwest Pacific's oldest-established Muslim communities.

29 The leading book on the Waitangi Tribunal process is Janine Hayward and Nicola Wheen, eds, The Waitangi Tribunal: Te Roopu Whakamana i te Tiriti o Waitangi, Wellington, 2004.

30 It would be invidious to cite any particular report, given the amount of work that has now been done, but it seems important to draw attention in particular to some of the fascinating new research being done for the current Northland Waitangi Tribunal regional inquiry, which all historians interested in the Treaty of Waitangi and the early phases of our history need to be aware of. See, for example, David Armstrong and Evald Subasic, Northern Land and Politics 1860-1910, Overview Report prepared for the Crown Forestry Rental Trust, two vols, June 2007, Wai 1040 Doc\# A12; Samuel D. Carpenter, Te Wiremu, Te Puhipi, He Whakaputanga me Te Tiriti: Henry Williams, James Busby, A Declaration and the Treaty, November 2009, Wai 1040 Doc\#A17; Vincent O'Malley and John Hutton, The Nature and Extent of Contact and Adaptation in Northland, Report Commissioned for the Crown Forestry Rental Trust, April 2007, Wai 1040 Doc\#A11.

31 R.P. Boast, Buying the Land, Selling the Land: Governments and Maori Land in the North Island 1865-1921, Wellington, 2008. Not everyone who works in this area agrees with me however.

32 I attempt to explore this complex question in my article, 'Lawyers, Historians, Ethics and the Judicial Process', VUWLR, 28, 1 (1998), pp.87-112. 


\section{NZ Legal History and NZ Historians}

33 Two prominent examples are Judith Binney, Encircled Lands: Te Urewera, 1820-1921, Wellington, 2009, and Vincent O'Malley and David Armstrong, The Beating Heart: A Political and Socio-economic History of Te Arawa, Wellington, 2008. Both books derive from earlier commissioned research reports written for the Urewera Waitangi Tribunal inquiry, in the case of Encircled Lands, and for the Central North Island inquiry and for the negotiation and settlement of Te Arawa historic claims, in the case of The Beating Heart. My Buying the Land, Selling the Land also largely derives from commissioned research carried out by myself for a number of Waitangi Tribunal historic inquiries.

34 I must record here that since this paper was presented Dr Dorsett has returned home to Australia and is now based at Sydney University of Technology. Their gain is our very great loss.

35 See http://www.victoria.ac.nz/law/nzlostcases/default.aspx

36 See http://www.victoria.ac.nz/law/PROJECTS/MaoriProject.aspx

37 See for example, William F. Hanks, Converting Words: Maya in the Age of the Cross, Berkeley and Los Angeles, 2010; James Lockhart, 'Between the Lines', in his Of Things of the Indies: Essays Old and New in Latin American History, Stanford, 1999, pp.22980; Matthew Restall, The Maya World: Yucatec Culture and Society, Stanford, 1997; Kevin Terraciano, The Mixtecs of Colonial Oaxaca, Stanford, 2001. 
Journal of New Zealand Studies 